\title{
Preliminary trials of the BioBaler working in Brazilian eucalypt plantations
}

\section{Saulo PS Guerra, Guilherme Oguri, Marcelo S Denadai, Maura ST Esperancini \& Raffaele Spinelli}

To cite this article: Saulo PS Guerra, Guilherme Oguri, Marcelo S Denadai, Maura ST Esperancini \& Raffaele Spinelli (2018) Preliminary trials of the BioBaler working in Brazilian eucalypt plantations, Southern Forests: a Journal of Forest Science, 80:2, 131-135, DOI: $10.2989 / 20702620.2017 .1292441$

To link to this article: https://doi.org/10.2989/20702620.2017.1292441

冓 Published online: 02 May 2017.

Submit your article to this journal

Џ Article views: 21

View Crossmark data \lceil 


\title{
Preliminary trials of the BioBaler working in Brazilian eucalypt plantations
}

\author{
Saulo PS Guerra1', Guilherme Oguri¹, Marcelo S Denadai'1, Maura ST Esperancini ${ }^{1}$ and Raffaele Spinelli2* \\ ${ }_{1}^{1}$ College of Agricultural Sciences, São Paulo State University, Botucatu, São Paulo, Brazil \\ ${ }^{2}$ Consiglio Nazionale delle Ricerche, Istituto per la valorizzazione del legno e delle specie arboree (CNR-IVALSA), Sesto \\ Fiorentino, Italy \\ *Corresponding author, email: spinelli@ivalsa.cnr.it
}

\begin{abstract}
The increasing demand for renewable energy feedstock has raised interest in growing eucalypts for fuel wood production, which is achieved by establishing very dense plantations cut every 18-24 months. The high moisture content of fresh Eucalyptus may handicap cut-and-chip operations, and offers a unique opportunity for supply chains based on baling. Therefore, the Canadian-made BioBaler was tested in Brazil on a eucalypt energy plantation, as well as on the resprouts generated by a conventional pulpwood plantation after severe frost damage. The BioBaler coped well with both crops, achieving high productivity levels: 7.1 and $3.3 \mathrm{t} \mathrm{h}^{-1}$ in the energy plantation and the failed crop treatments, respectively. Harvesting cost was estimated at $€ 13 \mathrm{t}^{-1}$ and $€ 26 \mathrm{t}^{-1}$ for the energy plantation and the failed crop, respectively. Productivity and harvesting cost were comparable with those reported in previous studies conducted in other countries on similar crops. Productivity was directly proportional to field stocking. Future studies should test the machine on a wider range of work conditions and include bale extraction, storage, processing and transportation, in order to estimate an overall supply chain cost and allow direct comparison with alternative options.
\end{abstract}

Keywords: biomass, cost, efficiency, energy, productivity

\section{Introduction}

Plantation forestry is well established in Brazil, where it covers over 6 million ha and yields 184 million $\mathrm{m}^{3}$ of round wood (FAO 2009). Favourable soil and climate conditions, together with the progress of genetic selection result in exceptional growth rates (Stape et al. 2010), and the area covered with fast-growing plantations in Brazil is expected to grow significantly in the next decades. Brazilian eucalypt plantations are planted at $3 \mathrm{~m} \times 2 \mathrm{~m}$ spacing, cut at age 7 years and yield over $250 \mathrm{~m}^{3}$ pulpwood ha-1 (ABRAF 2011).

However, the increasing demand for renewable energy feedstock has raised interest in growing eucalypts for fuel wood production (Couto et al. 2011). The quality requirements of energy wood are lower than for pulpwood, which may justify higher densities and shorter rotations in order to maximise yield (Gonzalez et al. 2011). New high-density plantations could be established at a $3 \mathrm{~m} \times 1 \mathrm{~m}$ spacing and cut at age 2 years, yielding up to $100 \mathrm{t} \mathrm{ha}^{-1}$ dry matter, or $1000 \mathrm{GJ} \mathrm{ha}^{-1}$ (Guerra et al. 2014). Under these conditions, the conventional harvesting techniques used for pulpwood are a poor choice because of suboptimal stem size, and they should be replaced with swathe harvesting, as already applied in European energy forests (Spinelli et al. 2011). Unfortunately, fresh Eucalyptus has a high moisture content, which may prove a handicap for cut-andchip operations: fresh chips are very difficult to dry, and high moisture content detracts from fuel quality (Civitarese et al. 2015). Furthermore, fresh wood chips are subject to rapid decay, which results in high dry-matter losses (Barontini et al. 2014) and a reduction of energy content (Pecenka et al. 2014). Ideally, stems should be cut and left to dry, before comminution. However, two-pass harvesting generally incurs higher costs than single-pass harvesting, which may discourage separate cutting and collection of the loose stems (Berhongaray et al. 2013).

An interesting alternative is offered by a relatively new machine that cuts and bales the stems, after a coarse mastication aimed at softening the stems, rather than finely comminuting them. This would allow easy handling and storage of uncomminuted stems, which could shed water without incurring substantial dry-matter losses (Stolarski et al. 2015). Built by Anderson Manufacturing and sold under the commercial name BioBaler, this machine offers the main advantage of cutting the stems and packing them into regular and dense units, which are easy to handle and store. The machine has been successfully tested under different work conditions, including those offered by European-style short-rotation forestry plantations, established with willows (Savoie et al. 2013). However, Brazilian eucalypt plantations may offer different and challenging conditions to the new machine, especially for what concerns stem size, moisture content and stringy bark - all generally higher than those found in willows.

Furthermore, the BioBaler is a very versatile machine, capable of handling a rather wide range of site conditions, and therefore it could be deployed on other potential energy wood sources, not just on dedicated energy plantations. One such additional source is the premature harvest of 
failed crops, i.e. conventional plantations that have suffered irreparable damage before reaching rotation age and must be terminated. These plantations often present stems that are too small for turning into anything else than bulk biomass, but may offer substantial amounts of raw product.

For this reason, the BioBaler was taken to Brazil for a preliminary test, with the main goal of gauging the productivity and cost of harvesting and baling (1) new dedicated energy wood plantations, established with eucalypts, and (2) the premature harvest of failed conventional plantations.

\section{Materials and methods}

The machine was tested on two separate blocks, representing the two cases described above. Both blocks were found at the same plantation, near Botucatu city, São Paulo State, Brazil. The plantation grew at an altitude of approximately $875 \mathrm{~m}$ above sea level and had been established with a hybrid of Eucalyptus grandis $x$ Eucalyptus urophylla (clone C219), at the standard spacing of $3 \mathrm{~m} \times 2 \mathrm{~m}$ (1 666 trees $\left.\mathrm{ha}^{-1}\right)$ on a medium-textured Oxisoil. Block 1 represented one of the new energy plantations and was 18 months old. Mean diameter at breast height $(\mathrm{DBH})$ was $7.5 \mathrm{~cm}$ and basal area was $17.2 \mathrm{~m}^{2} \mathrm{ha}^{-1}$. Block 2 was a conventional stand grown for pulpwood production that had been coppiced 18 months earlier and whose resprouting had been damaged by frost. For this reason, the stand was to be terminated and replanted (Table 1).

The machine was the standard Anderson WB55 BioBaler, towed and powered by a four-wheel-drive $160 \mathrm{~kW}$ Valtra BT210 tractor. Metal guarding was installed on the tractor to prevent damage to vulnerable mechanical components (i.e. diesel tank and hoses). The machine cut the stems, moved them to the compression chamber through hydraulic feed rollers and then packed them into round bales, with a diameter of $1.2 \mathrm{~m}$ and a height of $1.2 \mathrm{~m}$ (Figure 1).

The authors carried out a typical time-and-motion study, designed to evaluate machine productivity and to identify those variables that are most likely to affect it (Magagnotti et al. 2013). The production of a single bale was considered as the reference cycle, or repetition. Each cycle was timed individually with a stopwatch, separating

Table 1: Characteristics of the test sites. Different superscript letters within a row indicate a statistically significant difference $(p<0.05)$ between Block 1 and Block 2, estimated with the non-parametric Mann-Whitney $U$ test

\begin{tabular}{lcc}
\hline \multirow{2}{*}{ Characteristic } & \multicolumn{2}{c}{ Block } \\
\cline { 2 - 3 } & \multicolumn{2}{c}{2} \\
\hline Treatment & Energy plantation & Failed crop \\
Bale weight $(\mathrm{kg})$ & $505^{\mathrm{a}}$ & $539^{\mathrm{a}}$ \\
Location & Botucatu, São Paulo State, Brazil \\
Coordinates & $22^{\circ} 58^{\prime} 10^{\prime \prime} \mathrm{S}, 48^{\circ} 24^{\prime} 43^{\prime \prime} \mathrm{W}$ \\
Bale density $\left(\mathrm{kg} \mathrm{m}^{-3}\right)$ & $371^{\mathrm{a}}$ & $396^{\mathrm{a}}$ \\
Yield (bales ha $\left.{ }^{-1}\right)$ & $85.5^{\mathrm{a}}$ & $22.6^{\mathrm{b}}$ \\
Yield (t ha-1) & $43.2^{\mathrm{a}}$ & $12.2^{\mathrm{b}}$ \\
Moisture content (\%) & $65.7^{\mathrm{a}}$ & $72.7^{\mathrm{b}}$ \\
Bale weight (dry kg) & $173^{\mathrm{a}}$ & $147^{\mathrm{a}}$ \\
Dry matter yield $\left(\mathrm{t} \mathrm{ha}{ }^{-1}\right)$ & $14.8^{\mathrm{a}}$ & $3.3^{\mathrm{b}}$
\end{tabular}

productive time from delay time (Björheden et al. 1995). All delays were included in the study, not just the delays below a set duration threshold, because such practice may misrepresent the incidence of downtime (Spinelli and Visser 2009). However, delays that were caused by the study itself were removed from the data set. Productive time was divided into the following elements: cutting and collecting (machine moving forward); tying the bale (machine static with the rear gate closed); unloading the bale (the rear gate opens and the bale is dropped on the ground); and manoeuvre. Overall, the study included 28 cycles or bales.

Bale mass was determined by weighing all individual bales with a portable platform scale. Moisture content was determined by collecting 10 one-kilogram samples from the bales produced during the test. In particular, five samples were collected from each of the two treatments on test, selected randomly from the bales to be sampled. The sample included material extracted from the bale surface, as well as from its middle. Moisture content was determined with the gravimetric method according to the ASABE S358.2 standard (ASABE 2010).

Fuel consumption was determined by installing a volumetric flow meter on the tractor engine, and downloading all readings into a dedicated data logger.

Machine costs were calculated with the harmonised method developed within the scope of European COST
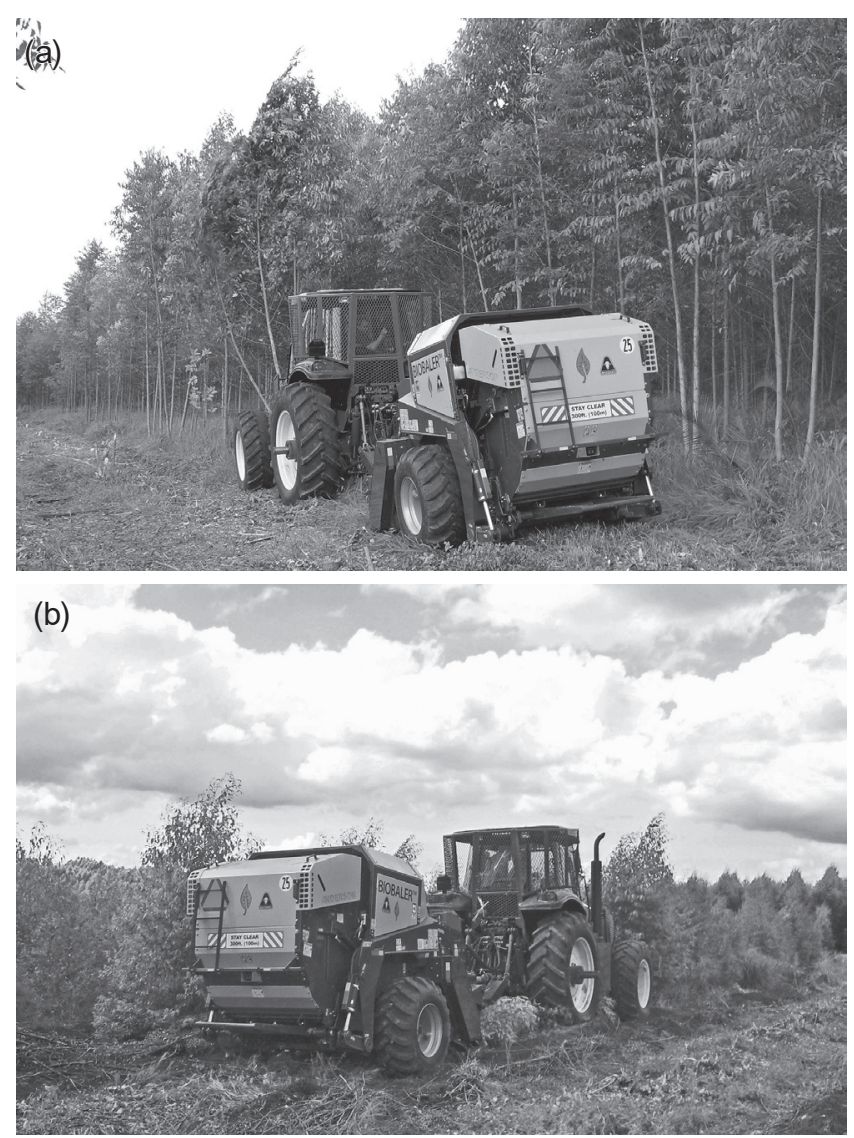

Figure 1: The BioBaler at work in the energy plantation (above) and in the failed crop (below) 
Action FP0902 (Ackerman et al. 2014). Data about utilisation, maintenance and value recovery were obtained directly from the BioBaler manufacturer and from the forest company providing the tractor and its driver (Table 2).

Data were analysed statistically using StatView for Windows 5.01 (SAS Institute, Cary, NC, USA). As a first step, descriptive statistics were extracted. The statistical significance of the differences between the two treatments was tested with the non-parametric Mann-Whitney $U$ test, in order to solve any issues related to violation of the statistical assumptions. The elected significance level for all tests was $\alpha=0.05$.

\section{Results}

Mean field yield was 3.5 times higher for the energy plantation than for the failed crop, at 43.2 and $12.2 \mathrm{t} \mathrm{ha}^{-1}$, respectively (Table 1). Moisture content was significantly different, and substantially higher for the failed crop (73\% vs $66 \%$ ), due to the abundant sprouting of new fresh leaves that immediately followed frost damage. In contrast, mean bale weight was similar for both treatments at about $500 \mathrm{~kg}$.

Production of a single bale took twice as long for the failed crop compared with the energy plantation (Table 3). This difference was due to a substantially longer cut-andcollect and manoeuvre time under the 'failed crop' treatment. In contrast, bale tying time, bale unloading time and delay time were similar under both treatments. Productivity was 6.5 and 14.1 bales $h^{-1}$ (or 3.3 and $7.1 \mathrm{t} \mathrm{h}^{-1}$ ) in the 'failed crop' and the 'energy plantation' treatments, respectively. Hourly fuel consumption was significantly lower when negotiating the failed crop, but not sufficiently low to offset the much lower productivity. As a consequence, fuel consumption per unit product was $50 \%$ higher for the failed crop, compared with the energy

Table 2: Cost calculations: assumptions, cost items and total cost

\begin{tabular}{lccc}
\hline & \multicolumn{3}{c}{ Block } \\
\cline { 2 - 4 } & 1 and 2 & 1 & 2 \\
\hline Treatment & Both & $\begin{array}{c}\text { Energy } \\
\text { plantation }\end{array}$ & $\begin{array}{c}\text { Failed } \\
\text { crop }\end{array}$ \\
Machine type & Biobaler & Tractor & Tractor \\
Machine make & Anderson & Valtra & Valtra \\
Machine model & WB 55 & BT 210 & BT 210 \\
Investment $(€)$ & 150000 & 55000 & 55000 \\
Resale $(€)$ & 15000 & 5500 & 5500 \\
Service life $(\mathrm{y})$ & 11 & 9 & 9 \\
Utilisation $\left(\mathrm{h} \mathrm{y}^{-1}\right)$ & 800 & 1500 & 1500 \\
Interest rate $(\%)$ & 12 & 12 & 12 \\
Depreciation $\left(€ \mathrm{y}^{-1}\right)$ & 12273 & 5500 & 5500 \\
Interest $\left(€ \mathrm{y}^{-1}\right)$ & 10636 & 3960 & 3960 \\
Insurance $\left(€ \mathrm{y}^{-1}\right)$ & 0 & 2500 & 2500 \\
Diesel $\left(€ \mathrm{y}^{-1}\right)$ & 0 & 28650 & 19950 \\
Lube $\left(€ \mathrm{y}^{-1}\right)$ & 0 & 8595 & 5985 \\
Repairs $\left(€ \mathrm{y}^{-1}\right)$ & 6136 & 5500 & 5500 \\
Total $\left(€ \mathrm{~h}^{-1}\right)$ & 36 & 36 & 29 \\
Crew $(n)$ & 0 & 1 & 1 \\
Labour $\left(€ \mathrm{~h}^{-1}\right)$ & 0 & 6 & 6 \\
Overheads $\left(€ \mathrm{~h}^{-1}\right)$ & 7 & 8 & 7 \\
Total rate $\left(€ \mathrm{~h}^{-1}\right)$ & 44 & 51 & 42 \\
\hline
\end{tabular}

plantation. Harvesting cost was $€ 13 \mathrm{t}^{-1}$ and $€ 26 \mathrm{t}^{-1}$ for the energy plantation and the failed crop, respectively.

Capital cost represented the majority of the total harvesting cost, immediately followed by operating cost. Labour cost contributed very little to total harvesting cost (Figure 2).

\section{Discussion}

Readers must be warned that this is a preliminary study, conducted on relatively small sample plots, because the

Table 3: Time and fuel consumption, productivity and cost. Values are means with the SD in parentheses. Net productivity = productivity calculated on net work time, excluding delays; gross productivity $=$ productivity calculated on total work time, including delays; $t=$ tonnes fresh matter; $p=$ statistical significance of the difference between Block 1 and Block 2, estimated with the non-parametric Mann-Whitney $U$ test

\begin{tabular}{|c|c|c|c|}
\hline & \multicolumn{2}{|c|}{ Block } & \multirow[b]{2}{*}{$p$} \\
\hline & 1 & 2 & \\
\hline Treatment & $\begin{array}{l}\text { Energy } \\
\text { plantation }\end{array}$ & $\begin{array}{l}\text { Failed } \\
\text { crop }\end{array}$ & \\
\hline Observations $(n)$ & 14 & 14 & \\
\hline Cut-and-collect time (s bale $\left.{ }^{-1}\right)$ & $137(39)$ & $356(87)$ & $<0.0001$ \\
\hline Tying time (s bale $\left.{ }^{-1}\right)$ & $42(6)$ & $41(2)$ & 0.8144 \\
\hline Unloading time $\left(\mathrm{s} \mathrm{bale}^{-1}\right)$ & $26(6)$ & $27(13)$ & 0.3405 \\
\hline Net work time $\left(\mathrm{s}\right.$ bale $\left.^{-1}\right)$ & $205(33)$ & $424(86)$ & $<0.0001$ \\
\hline Manoeuvre time (s bale $\left.{ }^{-1}\right)$ & $0(0)$ & $45(38)$ & $<0.0001$ \\
\hline Other delays (s bale ${ }^{-1}$ ) & $55(74)$ & $82(110)$ & 0.4888 \\
\hline Total time $\left(\mathrm{s}\right.$ bale $\left.^{-1}\right)$ & $256(86)$ & $551(130)$ & $<0.0001$ \\
\hline Net productivity (bales $\mathrm{h}^{-1}$ ) & $17.6(3.3)$ & $8.5(2.4)$ & $<0.0001$ \\
\hline Gross productivity (bales $\mathrm{h}^{-1}$ ) & $14.1(5.0)$ & $6.5(2.5)$ & $<0.0001$ \\
\hline Net productivity $\left(\mathrm{t} \mathrm{h}^{-1}\right)$ & $8.9(1.6)$ & $4.6(1.2)$ & $<0.0001$ \\
\hline Gross productivity $\left(\mathrm{t} \mathrm{h}^{-1}\right)$ & $7.1(2.5)$ & $3.3(1.3)$ & $<0.0001$ \\
\hline Fuel consumption $\left(\mathrm{L} \mathrm{h}^{-1}\right)$ & $19.1(3.7)$ & $13.3(1.5)$ & $<0.0001$ \\
\hline Fuel consumption $\left(\mathrm{L} \mathrm{bale}^{-1}\right)$ & $1.4(0.5)$ & $2.0(0.5)$ & $<0.0001$ \\
\hline Fuel consumption $\left(\mathrm{L} \mathrm{t}^{-1}\right)$ & $2.7(0.9)$ & $4.0(0.9)$ & $<0.0001$ \\
\hline Cut-and-bale cost $\left(€ \mathrm{t}^{-1}\right)$ & $13.3(4.5)$ & $25.9(6.1)$ & $<0.0001$ \\
\hline
\end{tabular}

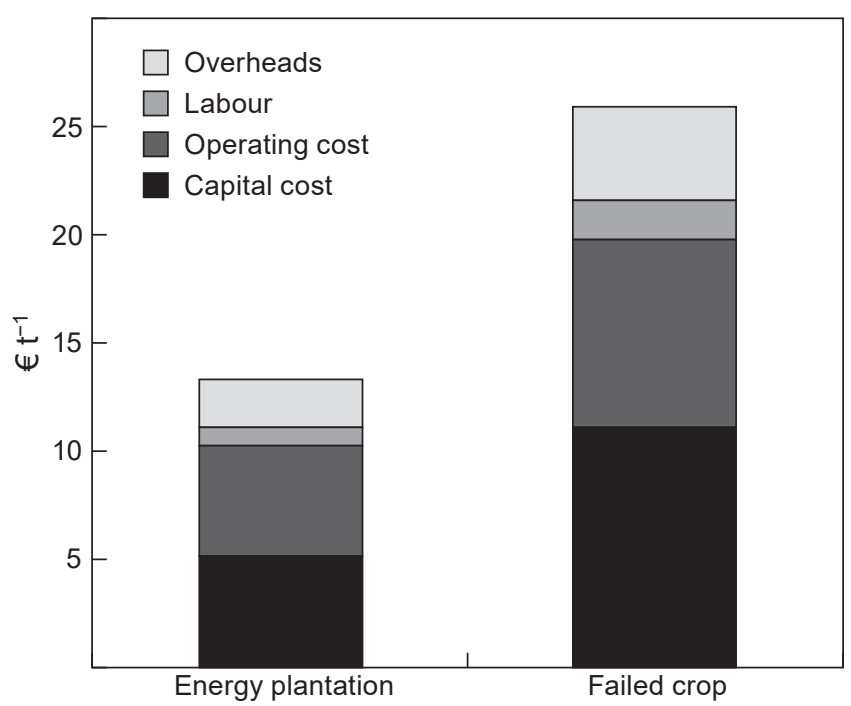

Figure 2: Breakdown of harvesting cost among different cost items 
machine could not be made available for a longer and more informative follow-up. For this reason, the results of this study should be generalised with caution, and must be taken as indicative rather than conclusive. However, studies have been conducted with the same machine on similarly small production batches, which have been published in reputable scientific journals after strict peer-reviewing (Canto et al. 2011; Savoie et al. 2013). Furthermore, this is the only study available to date regarding the use of the BioBaler in Eucalyptus energy plantations, which makes it rather valuable, especially if one considers the large potential of these plantations and the keen interest in developing new harvesting techniques that can cope with the very high moisture content of eucalypt wood.

The results of the present study are corroborated by those obtained in previous studies with the same machine (Table 4). This applies to the absolute productivity values, as well as the trends. The productivity values recorded in this study are well within the $2-19 \mathrm{t} \mathrm{h}^{-1}$ range spanned by previous tests, which were conducted with the BioBaler under a wide variety of different conditions. Concerning trends, this study shows that productivity increases with field yield, as observed previously by other authors who have tested the BioBaler (Savoie et al. 2009, 2013). In fact, the direct relationship between field stocking and productivity seems to be a general rule for swathe harvesting, and especially for the harvesting of short-rotation energy plantations with single-pass continuous harvesting machinery (Spinelli et al. 2009). Given that most of these machines have a definite working speed, it stands to reason that the higher the field stocking, the higher the productivity - at least if field stocking does not attain the maximum capacity of the machine. In this case, one may assume that the $15 \mathrm{t} \mathrm{ha}^{-1}$ stocking recorded on Block 1 is well within the maximum capacity of the BioBaler, which is further supported by the fact that other studies with the same machine report successful harvesting for much higher field stocking values, up to $50 \mathrm{t} \mathrm{ha}^{-1}$ (Savoie et al. 2013). This is especially important, if one considers that Brazilian energy plantations may attain stocking in excess of $100 \mathrm{t} \mathrm{ha}^{-1}$ (Guerra et al. 2014).

The above-mentioned relationship between field stocking and productivity may partly explain the different results obtained in the two test blocks, where a higher productivity was achieved on the richer block. This was also shown by the much longer cut-and-collect time, which was due to the need to cover a longer distance in order to fill up the compression chamber. On the other hand, the extended manoeuvre time hints at access difficulties, more than

Table 4: Comparison with other studies. SRC = short-rotation coppice

\begin{tabular}{lcccl}
\hline Stand & Country & $\mathrm{t} \mathrm{ha}^{-1}$ & $\mathrm{t} \mathrm{h}^{-1}$ & \multicolumn{1}{c}{ Reference } \\
\hline Eucalypt & Brazil & $3-15$ & $6.5-14$ & This study \\
Natural willow & Canada & $12-45$ & $3.5-6.6$ & Savoie et al. (2009) \\
Undergrowth & USA & $\sim$ & $\sim 2$ & Canto et al. (2010) \\
SRC willow & Canada & $23-26$ & $5-8$ & Lavoie et al. (2007) \\
SRC willow & Canada & $17-50$ & $7-19$ & Savoie et al. (2013) \\
SRC willow & Poland & 40 & 8.7 & Stolarski et al. (2015) \\
\hline
\end{tabular}

likely related to the presence of tall and large stumps that the machine had to straddle with much care. In that regard, it is important to stress that Block 2 was a conventional pulpwood plantation, not one of the new energy plantations. For that reason, the stand had been harvested with ordinary logging machinery, which had left relatively tall stumps. Furthermore, the stocking available on Block 2 was much lower than normally encountered when harvesting the new energy plantations after 18 months of full growth. Therefore, Block 2 is not representative of second- and third-rotation energy plantations, which will need to be tested separately in future research.

Harvesting cost for the energy plantation was relatively low and in line with the $€ 16 \mathrm{t}^{-1}$ reported for Canada (Savoie et al. 2013). This cost is also substantially lower than the $€ 40 \mathrm{t}^{-1}$ reported for the USA (Canto et al. 2011), although in the latter case the BioBaler was used under much less favourable conditions and the comparison should be made with the results obtained for Block 2, not Block 1. Of course, any comparisons of costs should account for the very different economic conditions of the countries where the tests took place. In particular, Brazilian labour rates are especially low and play a major role in cost containment. On the other hand, the investment cost estimated for the BioBaler in Brazil is twice as high as that considered in Canada or the USA, due to the very high import taxes imposed by the Brazilian Government in order to protect national industries. If these taxes were removed or if a Brazilian manufacturer was licensed to build the BioBaler, then investment cost would be dramatically reduced and harvesting cost would drop to $€ 11 \mathrm{t}^{-1}$ and $€ 20 \mathrm{t}^{-1}$ for the energy plantation and the failed crop, respectively.

Furthermore, one may expect significant productivity improvements as the operators gain experience with the new technique. The operator used during the test was well acquainted with the machine, but he had been driving it on Eucalyptus only for a few hours before commencing the assessment. Therefore, it is very likely that the same assessment repeated after several months of prolonged use with Eucalyptus will offer better results.

\section{Conclusions}

This preliminary test showed that the BioBaler can work efficiently with eucalypts grown for energy use, and it can achieve encouraging productivity levels. Further studies should expand the range of work conditions, and include bale extraction, storage, processing and transportation, so as to estimate an overall supply-chain cost and allow direct comparison with the alternatives. In such an endeavour, one should carefully consider storage efficiency, which is one of the main assets of any supply chain based on baling.

Acknowledgements - Special thanks are due to Siltomac Industries and to the Anderson Group for assisting with the trials, and in particular for making the BioBaler team available.

\section{References}

ABRAF (Brazilian Association of Forest Plantation Producers). 2011. ABRAF statistical yearbook 2011. Brasília, DF: ABRAF. 
Ackerman P, Belbø H, Eliasson L, de Jong A, Lazdins A, Lyons J. 2014. The COST model for calculation of forest operations cost. International Journal of Forest Engineering 25: 75-81.

ASABE (American Society of Agricultural and Biological Engineers). 2010. Standard S358.2. Moisture measurement - forages. St Joseph, MI: ASABE.

Barontini M, Scarfone A, Spinelli R, Gallucci F, Santangelo E, Acampora A, Jirjis R, Civitarese V, Pari L. 2014. Storage dynamics and fuel quality of poplar chips. Biomass and Bioenergy 62: 17-25.

Berhongaray G, El Kasmioui O, Ceulemans R. 2013. Comparative analysis of harvesting machines on an operational high-density short rotation woody crop (SRWC) culture: one-process versus two-process harvest operation. Biomass and Bioenergy 58: 333-342.

Björheden R, Apel K, Shiba M, Thompson M. 1995. IUFRO forest work study nomenclature. Garpenberg: Swedish University of Agricultural Science, Department of Operational Efficiency.

Canto J, Klepac J, Rummer B, Savoie P, Seixas F. 2011. Evaluation of two round baling systems for harvesting understory biomass. Biomass and Bioenergy 35: 2163-2170.

Civitarese V, Spinelli R, Barontini M, Gallucci F, Santangelo E, Acampora A, Scarfone A, del Giudice A, Pari L. 2015. Open-air drying of cut and windrowed short-rotation poplar stems. Bioenergy Research 8: 1614-1620.

Couto L, Nicholas I, Wright L. 2011. Short rotation eucalypt plantations for energy in Brazil. IEA Bioenergy Task 43 Technical Report 2011:2. Rotorua: IEA Bioenergy Secretariat.

FAO (Food and Agriculture Organization of the United Nations). 2009. Responsible management of planted forests: voluntary guidelines - preparation for action - the country level methodology. Planted Forests and Tree Working Paper 45/E. Rome: FAO.

Gonzalez R, Treasure T, Wright J, Saloni D, Phillips R, Abt R, Jameel H. 2011. Exploring the potential of Eucalyptus for energy production in the southern United States: financial analysis of delivered biomass. Part I. Biomass and Bioenergy 35: 755-766.

Guerra S, Garcia E, Lanças K, Rezende M, Spinelli R. 2014. Heating value of eucalypt wood grown on SRC for energy production. Fuel 137: 360-363.

Magagnotti N, Kanzian C, Schulmeyer F, Spinelli R. 2013. A new guide for work studies in forestry. International Journal of Forest Engineering 24: 249-253.

Pecenka R, Lenz H, Idler C, Daries W, Ehlert D. 2014. Development of bio-physical properties during storage of poplar chips from 15 ha test fields. Biomass and Bioenergy 65:13-19.

Savoie P, Hébert P-L, Robert F-S, Sidders D. 2013. Harvest of short-rotation woody crops in plantations with a biobaler. Energy and Power Engineering 5(2A): 39-47.

Savoie P, Lavoie F, D'Amours L. 2009. Development of two headers for a versatile woody brush harvester-baler. Applied Engineering in Agriculture 25: 811-817.

Spinelli R, Magagnotti N, Picchi G, Lombardini C, Nati C. 2011. Upsized harvesting technology for coping with the new trends in short-rotation coppice. Applied Engineering in Agriculture 27: $551-557$.

Spinelli R, Nati C, Magagnotti N. 2009. Using modified foragers to harvest short-rotation poplar plantations. Biomass and Bioenergy 33: 817-821.

Spinelli R, Visser R. 2009. Analyzing and estimating delays in wood chipping operations. Biomass and Bioenergy 33: 429-33.

Stape JL, Binkley D, Ryan MG, Fonseca S, Loos RA, Takahashi EN, Silva CR, Silva SR, Hakamada RE, Ferreira JMA, Lima AMN, Gava JL, Leite FP, Andrade HB, Alves JM, Silva GGC, Azevedo MR. 2010. The Brazil Eucalyptus Potential Productivity Project: influence of water, nutrients and stand uniformity on wood production. Forest Ecology and Management 259: 1684-1694.

Stolarski M, Krzyżaniak M, Szczukowski S, Tworkowski J, Grygutis J. 2015. Changes of willow biomass quality as a renewable energy feedstock harvested with biobaler. Journal of Elementology 20: $717-730$. 